\title{
A Literature Review of Various Approaches, Conditions, and Factors That Become Earning Management Motives
}

\author{
Hendry Kurniawan ${ }^{1}$, Ahmad Syifaudin ${ }^{2}$, Nurasiah ${ }^{3}$, Hanif Rani Iswari ${ }^{4}$ \\ ${ }^{1}$ Universitas Pasir Pengaraian \\ ${ }^{2}$ Universitas Swadaya Gunung Jati \\ ${ }^{3}$ Sekolah Tinggi Ilmu Ekonomi Pontianak \\ ${ }^{4}$ Universitas Widyagama Malang \\ Hendrykurniawan@upp.ac.id,ahmad.syifaudin@gmail.com,nurasiah.ptkacd@gmail.com, \\ rani@widyagama.ac.id4
}

\begin{abstract}
This study aims to understand both the company's internal and external conditions that affect earnings management actions as well as approaches to earnings management. The approach in this study uses a qualitative descriptive approach. The approach used in this research is to use a literature review approach. The results show that from 10 previous studies both national and international, earning management is a manager's effort to produce financial figures that are not accurate in order for the manager's financial performance to appear good to shareholders. Earnings management is linked to one of the great theories, agency theory. Taking a bath, income minimization, income maximization, and income smoothing are four patterns of earning management that are well-known. Real earnings management and accrual earnings management are two strategies that are frequently employed in earnings management. Earning management is also influenced by the company's financial and non-financial conditions. However, several previous studies have different results with various explanations. It is known that this difference is caused by different periods, company objects and different research backgrounds.
\end{abstract}

Keywords

Literature; conditions; earning management

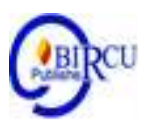

\section{Introduction}

A company is established with the intention of obtaining the maximum possible profit and maintaining the viability of the company in the future. In order for this purpose to be realized, the company must be able to maximize the empowerment of existing resources in an appropriate and efficient way (E Janrosl \& Lim, 2019). Financial statements are a structured presentation that illustrates a company's financial situation and financial performance, as well as information about the company's financial condition, financial management performance, and cash management, which can assist report users in making business decisions. The financial statements serve as a medium of accountability for managers to owners, investors and creditors use them as a tool for making investment and loan decisions while the board of directors uses them to oversee the actions of managers (Wibowo \& Herawaty, 2019). Financial reports are also a form of information needed, especially for investors and creditors. External consumers will be interested in these financial figures, especially because this group is in the most precarious position. Because of the asymmetry between management and owners, managers may be tempted to take activities that are harmful to the organization. In order for financial information to entice investors and creditors to invest in the company, company executives may take a 
number of steps to make the financial statements look attractive. If the company isn't doing well, managers often manipulate data in this way to make it look like the company is doing well, even though the company isn't. This is done by the company's management to keep investors happy and bring in new ones. So, management plays a big part in making sure that the company's financial statements are both accurate and up-to-date (Niranda \& Muid, 2020).

The higher the company's leverage, the company tends to generate less cash, this is likely to affect the occurrence of earning management. Companies with high debt or leverage ratios tend to hold their profits and prioritize the fulfillment of debt obligations first. According to Brigham and Ehrhardt (2013), the greater the leverage of the company, it tends to pay lower dividends in order to reduce dependence on external funding. So that the greater the proportion of debt used for the capital structure of a company, the greater the number of liabilities that are likely to affect shareholder wealth because it affects the size of the dividends to be distributed. (Yanizzar, et al. 2020)

Development is a systematic and continuous effort made to realize something that is aspired. Development is a change towards improvement. Changes towards improvement require the mobilization of all human resources and reason to realize what is aspired. In addition, development is also very dependent on the availability of natural resource wealth. The availability of natural resources is one of the keys to economic growth in an area. (Shah, M. et al. 2020)

Management actions in manipulating financial statements as mentioned above, are known as earnings management is profit engineering carried out by managers in earnings management, which is strongly linked to a company's profit or achievement. Earnings management is a change in how financial reporting is done by the company's managers. One of the goals is to change how much profit is shown in the company's financial statements. As a result, it is not surprising that managers frequently try to highlight their achievements by the level of earnings or profits achieved. (Ningsih, 2017). Because earnings management causes the appearance of financial information to not represent the actual situation, it is always connected with negative behavior. This is due to the unequal connection that exists between management, stockholders, and interested parties with varying levels of priority. By raising the company's profit for the year in question, management hopes to earn a large bonus. Meanwhile, shareholders are attempting to limit their gains for a variety of reasons, including the desire to reclaim their shares.

Earning management is divided into two categories of approaches, namely Real Earning Management and Accrual Earning Management. In research (Graham et al., 2005) Top management as respondents is much more willing to engage in real earnings management than accrual earnings management to achieve profit targets. Accrual Earning Management can be measured both short term and long term discretionary accruals. Meanwhile, Real Earning Management can be measured by abnormal CFO, abnormal Production Costs, and abnormal Discretionary Expenses. However, these two categories of approaches are considered by some researchers to be still unable to reveal complete conditions regarding earnings management practices because these approaches ignore the relationship between cash flow transactions and accruals.(Ningsih, 2017). This earning management practice begins with the existence of information asymmetry in which the management knows more about internal information and the company's prospects in the future than stakeholders. Agency theory is one of the theories that form the basis for the practice of earnings management. Where it starts from the separation between ownership rights and company management, namely when one or more principals involve other 
people as their agents who are tasked with providing services for the interests of the principal.

Based on the above, seen from the category of earning management approach is susceptible to being influenced by the company's internal and external variables. Therefore, based on the literature study, we want to know how financial and non-financial conditions can affect earnings management actions and the extent to which both approaches, both real earnings management and accrual earnings management, can show conditions regarding earnings management practices.

\section{Review of Literature}

\subsection{Agency Theory}

Agency theory can explain how earnings management arises. Theoretically, agency theory supports the company's current business practices. Economic theory, decision theory, sociology, and organizational theory all contribute to the theory's foundation. Understanding the issue of earnings management is based on the agency theory approach. The "nexus of contract" idea asserts that there is a working relationship between the person who gives the principal authority, namely the investor, and the party who receives the agency's authority, namely the management, in the form of a cooperation contract (Herawaty, 2008).

As an agent, the manager is morally responsible for optimizing the profits of the owners (principals) and in return will be compensated according to the contract. However, managers or company managers in carrying out their activities sometimes try various opportunities to fulfill their interests as personal interests and do not always carry out activities only to fulfill the best goals of agents. The existence of differences in interests can result in actions taken by management not always achieving the best goals of the interests of shareholders (Astuti \& Pangestu, 2019). Agency theory is needed to solve two problems that can happen in agency relationships. The first problem is caused by the agent and the principal having different goals or interests. The second problem is how the principal and agent will share the risk because they have different attitudes about taking risks.

\subsection{Earnings Management}

Earning management is the manager's endeavor to present financial statements that do not accurately reflect the manager's true financial condition for the manager's advantage so that the manager's financial performance seems to be satisfactory to the principle (Wibowo \& Herawaty, 2019). Earning management is accomplished by manipulating the accrual components of financial statements, because the accruing component may be manipulated with numbers using the accounting system of the person who records and generates financial accounts (Sari \& Ahmar, 2014). There are two techniques that are often used in earnings management, namely Real Earning Management and Accrual Earning Management. Manipulating earnings by using different accounting procedures and accounting methods without affecting cash flows directly and in accordance with GAAP rules is called accrual earnings management. Accrual earning management provides a true picture of the financial position of a company in the future because the accrual process will produce smoother profits but are less consistent and relatively dependent on management's assessment of the company's financial condition when compared to real earnings management (Lin \& Hwang, 2010). 
The difference between non-discretionary and discretionary accruals is the difference between the net cash inflows from operations and the profit recorded on the income statement. The financial statements are prepared on an accrual basis, which implies that they will contain both discretionary and non-discretionary accrual components. Earnings management is possible by manipulation of pure accruals, that is, accruals that have no direct impact on cash flows (Roychowdhury, 2006). However, discretionary accruals cannot be observed directly from the financial statements. Usually accrual management is carried out at the end of the period when managers know earnings before they are engineered so they can find out how much manipulation is needed to achieve profit targets. Real earnings management, on the other hand, is a manipulation that is carried out by directly influencing the cash flows that enter the company by changing the time or date in making investments and additional capital or finance, or making changes to the structure of operations, regulating the timing of the sale of fixed and marketable assets securities when operating income declines to exceed management's expectations, (Gunny, 2010). There are four types of earnings management, according to (Scott, 2007) :

a. Taking a bath

Taking a bath is a pattern of profit management in which the company's profit in the present period is either very low (loss) or very high (profit) when compared to profits in prior or subsequent periods.

b. Income minimization

Income minimization is a pattern of profit management in which the profit reported in the current period's financial statements is less than the actual profit.

c. Income maximization

Income maximization is a pattern of profit management in which the profit reported in the current period's financial statements is higher than the actual profit.

d. Income Smoothing

Income smoothing is a type of earnings management in which accounting profit is kept reasonably steady (smooth) from one period to the next.

\section{Research Method}

This type of research will be done with qualitative methods in it. The method used in this research is to look at other people's work and see what they say. Cooper in (Creswell, 2010) says that a literature review has a number of goals, including informing readers of the results of other studies that are closely related to the research being done at the time, connecting the research to the existing literature, and filling in gaps in previous studies. The literature review also includes reviews, summaries, and thoughts from the author. In this section, we'll talk about a lot of different library resources that can help you learn about the topics we're going to cover. This study looks at how financial and non-financial factors, as well as approaches and factors that can lead to earnings management, affect these things.

The technique used in this research is to collect and document existing research that is in accordance with the research focus. The data analysis technique that has been obtained in this research is by analyzing the data (case studies) with relevant theories. After the analysis, conclusions can be drawn from the case study analysis with the relevant theories used. The steps used in data analysis are:

1. Collect case studies (previous research) related to this research.

2. Classification process to obtain the required data.

3. Comparison and analysis of the literature review with the theories used.

4. Describe and draw conclusions and suggestions from this research 


\section{Results and Discussion}

\subsection{Data Analysis Results}

a. Analysis Of Affecting Factors Earning Management (Empirical Study of Manufacturing Companies Listed on the Stock ExchangeIndonesia 2016-2017)

This research was conducted by Hafiz Gavra Niranda and Dul Muid (2020). Earnings management is harmed by low-quality audits, but the audit committee is harmed by highquality audits. While last year's profits don't have a big impact on earnings management, neither does the size of the company.

b. The Effect of Profitability Ratio, Free Cash Flow, and Leverage Against Earnings Management

This research was conducted by Desi Jelanti (2020). People who have looked at the data have found out that profitability has no big impact on how earnings are managed, so they don't need to worry about it. This means that the first hypothesis in this study didn't hold up. Income management doesn't seem to be affected by free cash flow. To make sure that the second hypothesis in this research is true. The third hypothesis in the study is that leverage has a big impact on earnings management, so this is true. Finally, profitability, free cash flow, and leverage all work together to have a big impact on how earnings are managed.

\section{c. Ownership Structure, Good Corporate Governance, Leverage, And Entity Size On Earnings Management}

This research was conducted by Syaiful Bahri and Yohanna Putri Arrosyid (2021). The result showed ownership structure with institutional ownership proxy has no effect to earnings management. Good corporate governance proxied by independent commissioners has no effect on earnings management. Leverage with DAR proxy has no effect on earnings management. And entity size has no effect on earnings management.

\section{d. Analysis Of Factors Affecting Earning Management In Manufacturing Companies Listed On Bei}

This research was conducted by Riza Ramadhan (2017). The findings of this study show that (1) the bonus plan (ROA) has a minor but significant detrimental impact on earnings management. The debt contract (leverage) has a good effect on earnings management but has no meaningful impact. In the meantime, political expenses (firm size) have a small but favorable impact on earnings management. (2) Earnings management is positively impacted by concurrent testing, bonus schemes (ROA), leverage contracts, and political costs (firm size).

e. Analysis Influence Of The Company Size, Average, Institutional Ownership, And Managerial Ownership On Earning Management

This research was conducted by Yogi Kusumawardana and Mulyo Haryanto (2019). This study shows that firm size has a significant effect on earnings management, leverage has no effect on earnings management, institutional ownership has no effect on earnings management, and managerial ownership has no effect on earnings management. 
f. The Effect Of Good Corporate Governance Mechanism And Corporate Social Responsibility On Financial Performance With Earnings Management As Mediating Variable

This research was conducted by Mayang Mahrani and Noorlailie Soewarno (2018). According to testing and analytical data, both the GCG mechanism and CSR have a positive impact on financial performance and earnings management. It has been established the critical nature of GCG mechanisms and CSR. Meanwhile, the test results and analysis indicate that earnings management had a significant adverse effect on financial success. Earnings management, on the other hand, can employ partial mediation to mitigate the GCG mechanism's effect on financial performance. The results of the testing and research indicate that earnings management can completely reduce the financial impact of CSR.

\section{g. Does Earning Management Happen In Islamic Bank? (Indonesia And Malaysia Comparison)}

This research was conducted by Adela Sarah Vania, Erik Nugraha, and Lucky Nugroho (2018). The Mann-Whitney Test is used in this study to see if there are any differences in earnings management methods between Islamic banking in Indonesia and Malaysia using discretionary accruals. In Indonesian Islamic banking, the average discretionary accrual is smaller than in Malaysian Islamic banking. This demonstrates that in Indonesian Islamic banking, the business of minimizing profit by management is more important than in Malaysian Islamic banking.

\section{h. Accrual Earning Management And Future Performance: Evidence From Family Firm In Indonesia}

This research was conducted by Edy Suprianto and Doddy Setiawan (2020). This study shows that the average value of a company's family future performance is higher than the average value of a non-family company's future performance. In addition, we believe that in Indonesia, earnings management is more opportunistic than efficient. Finally, larger auditing firms chosen by family businesses have a good impact on future results. This study shows that family businesses do better in the future than non-family businesses. According to the findings, investors should consider investing more in family businesses. To keep the family's good name, family businesses must operate well.

\section{i. Role Of Discretionary Earning Management In Corporate Governance-Value And Corporate Governance-Risk Relationships}

This research was conducted by Affaf Asghar, Seemab Sajjad, Aamer Shahzad and Bolaji Tunde Matemilola (2019). Tobin's Q and company risk do not appear to be affected by the size of the board (VOL). Tobin's Q is negatively affected by the audit committee's independence, however this effect is minimal when compared to the effects on business risk and Tobin's Q. While family ownership has a big beneficial impact on ROA, Tobin's Q has a negligible one. According to the data, CG factors like CEO duality, board independence and audit committee size all contribute to the enhancement of the CG system, which leads to enhanced company success. Enhanced audit quality, proper board monitoring, regular board meetings, and corporate codes of behavior can all assist alleviate the agency's concerns. Corporate value rises when management is discouraged from misrepresenting financial statements by sound oversight and monitoring procedures. 


\section{j. Earnings Management: A Strategic Adaptation Or Deliberate Manipulation?}

This research was conducted by Shathees Baskaran, Nalini Nedunselian, Chun Howe Ng, Nomahaza Mahadi and Siti Zaleha Abdul Rasid (2020). In light of the company's ethics and earnings management philosophy, the study produced research propositions. Another benefit was the conceptual framework it gave to explain the connection between having a moral frame of mind and a multifaceted approach to financial management. It is expected that the incorporation of investor sentiment and corporate social responsibility (CSR) as mediating and moderating variables in this conceptual study will increase the predictive value of the proposed framework and provide additional insight into the factors that inhibit or advance an organization's ethical orientation and earnings management practices.

\subsection{Research Discussion}

As you can see from this example, earnings management is when the manager tries to make financial statements look better than they are to make it look like the manager's financial performance still looks good to shareholders, according to the results of data analysis. Earning management is linked to agency theory, in which the functions of organizational owners and organizational actors are separated. If the agent and the principle are both attempting to maximize their utility and have opposing wants and motivations, Reason to believe that the agent (management) does not always behave in the principal's best interest (stakeholders). Conflicts of interest might arise as a result of management reporting results in an opportunistic manner in order to further their own personal objectives. If this occurs, earning management will be implemented. According to the data research, there are four earning management patterns: (1) Taking a Bath: making the company's profit in the present period very low (loss) or very high (profit) in comparison to profits in the preceding period. (2) Income Minimization: reducing the profit reported in the current period's financial statements to a lower level than the real profit. (3) Income Maximization: increasing the profit for the present period over the actual profit. (4) Income Smoothing: maintaining a somewhat continuous (smooth) accounting profit from one period to the next.

There are two techniques that are often used in earnings management, namely Real Earning Management and Accrual Earning Management. Data analysis revealed that from research (Roychowdhury, 2006) introduced an earning management technique called real activity manipulation (Real Earning Management) This is described as the discrepancy between actual operating procedures and typical operating practices, prompted by management's intention to provide stakeholders a false impression so that they assume specific financial reporting objectives have been reached. in compliance with the company's standard operating procedures Although this move permits managers to meet reporting objectives, it does not contribute to firm value. Manipulation of real-world activities such as price reductions and reductions in discretionary expenditure, which may be the best course of action in some circumstances. However, if this is done more extensively than normal activities with the aim of achieving profit targets, then such actions can be categorized as real activity manipulation. (Roychowdhury, 2006) using a model from research (Dechow et al., 1996) focuses on 3 management methods, namely: (1) Sales management, defined as a management effort to increase sales temporarily by offering price discounts and softening credit. For example, an increase in sales volume as a result of offering discount prices at a certain time will cause cash inflows to be large, but sales cash inflows are lower than normal sales cash flows or in other words a decrease in margin. Another way that management uses to increase sales volume is by offering credit, 
such as offering zero percent financing when the fiscal year ends. This will increase the company's profits or cash inflows instantly. (2) Reducing discretionary expenditures such as research and development (R\&D), advertising, and maintenance which is generally an expense in the period in which the expenditure is incurred. Thus the company can reduce reported expenses so that it will increase profits. An example of management that is usually carried out by management related to discretionary expenses is if the expenditure on discretionary expenses is in the form of cash, then this reduction in expenditure will minimize cash outflows and will have a positive impact on abnormal Cash Flow from Operation (CFO) in the current period, but maybe vice versa. will also pose a risk of low cash flows in the future. (3) Overproduction, increasing production with the aim of reporting a lower Cost of Goods Sold (COGS). With high levels of production, fixed costs are spread over large units, resulting in lower fixed costs per unit. As long as the decrease in fixed cost per unit cannot be offset by an increase in marginal cost per unit, total cost per unit decreases. This results in lower reported COGS, and companies can report better operating margins.

The second technique that is known from the results of data analysis is through the Accrual Earning Management approach. Accrual is the difference between the company's operating results and its profit on the income statement. It can be a non-discretionary accrual or a discretionary accrual, and it can be both. When you make financial statements, they are based on the accrual process, which means that both discretionary and nondiscretionary accruals will show up in the financial statement figures. Research is based on what we learned from data analysis (Roychowdhury, 2006) can be done by manipulating pure accruals, namely discretionary accruals which have no direct influence on cash flows. However, discretionary accruals cannot be observed directly from the financial statements. Usually accrual management is carried out at the end of the period when managers know earnings before they are engineered so they can find out how much manipulation is needed to achieve profit targets. There are various motivations that encourage earning management. Positive Accounting Theory proposes three hypotheses of earning management motivation, namely: bonus plan hypothesis, debt covenant hypothesis, and political cost hypothesis. (1) The bonus plan hypothesis states that managers who have accounting incentives, or remuneration that is tied to the company's accounting performance will tend to manipulate accounting methods and numbers to show better performance than it should. Such a manager chooses to use a different depreciation method, allowing lower profits at the beginning and more profits towards the end. (2) Debt equity hypothesis, in this hypothesis the higher the debt or equity ratio of the company, the more likely it is for managers to choose accounting methods that can increase profits. The higher the debt or equity ratio, the closer the company is to the credit agreement or regulatory limit. The higher the credit limit, the greater the possibility of deviations from credit agreements and expenses. Managers will have accounting methods that can increase profits so as to relax credit limits and reduce the cost of technical errors. (3) Political cost hypothesis, in political cost theory, large companies will most likely use accounting methods that reduce reported earnings and or make other disclosures to reduce political costs.

In data analysis, it is known that several studies state that financial and non-financial conditions affect earnings management, but several other studies state that financial and non-financial conditions have no effect on earnings management. Several explanations regarding the influence and non-influence of financial and non-financial conditions. The company's financial condition from the results of data analysis such as profitability, leverage, liquidity, and sales growth, operating cash flow. And non-financial conditions 
include managerial ownership, institutional ownership, company size, audit quality, and audit committee. It is known that financial conditions affect earnings management, on the profitability of companies with low profitability have a negative impact on the company's performance appraisal, therefore managers are motivated to perform earnings management. High profitability also has the opportunity to carry out earnings management, this aims to reduce tax costs. So profitability has a positive effect on earnings management, this shows that the higher the profitability, the higher the earnings management. However, several studies show different results, high or low profitability obtained does not affect earnings management. This is due to the occurrence of profitability after the occurrence of earning management, so that it does not affect earnings management, the profit value obtained from the reduction after tax and interest is only found in profitability, and the higher the profitability, the larger the dividends distributed. Increasing profitability indicates good company performance and shareholders will receive increasing profits. Because the manager also gets a profit so he doesn't take earnings management actions. In other financial conditions such as leverage, several previous studies stated that leverage had no effect on earnings management. This indicates that the higher or lower leverage will not affect earnings management. This is because, companies usually do not depend on debt to finance company assets. so that it does not affect the company's management decisions in setting the amount of profit to be reported if there is a change in the level of debt. Other studies have different results, where a company with a high level of leverage means it has a greater liability when compared to its assets, this will result in great risk and pressure on the company. Companies that have leverage can be a measure of earnings management. Leverage increases investors' risk, and investors will demand more earnings. As a result, the higher the leverage, the more opportunity managers have to manage profitability. In the financial analysis of the data, it is well established that the size of the business has a substantial impact on earnings management. This shows that the larger the company, the less likely management will manipulate earnings. Because the company is getting bigger, the more stringent supervision of the company's internal parties. So as to minimize the actions of the company's management in committing fraud regarding earnings information. Large companies are better known and noticed by the government, investors and the general public, than small companies. Therefore, large companies are under stronger pressure to present credible financial statements and to avoid earnings management actions by keeping companies rated positively by the public. However, institutional ownership and managerial ownership show that institutional ownership has no effect on earnings management. This indicates that the higher or lower the share ownership portion owned by institutional parties, it is not very meaningful as a tool to monitor the actions of earnings management in the company in committing fraud regarding the profit information contained in the financial statements. Managerial ownership has no effect on earnings management. This shows that the greater the managerial ownership, the lower the earnings management actions taken by the company's management. So that the management will be more efficient in choosing accounting methods that provide added value for the company. 


\section{Conclusion}

It can be said that earning management is a manager's effort to make financial reports that don't match the real situation so that the manager's financial performance still looks good for shareholders. This is based on data analysis of 10 previous studies, both national and international. Also, one of the big theories, called "agency theory," has to do with how to make money. Taking a Bath, Income Minimization, Income Maximization, and Income Smoothing are some of the ways people manage their money. A lot of people use two different ways to manage their earnings, called "Real Earning Management" and "Accrual Earning Management." Financial and non-financial factors can also play a role in how the company manages its earnings. However, in data analysis, there are still some results that don't agree with each other.

Based on the results of data analysis from 10 previous studies, both national and international, it is stated that the management in carrying out earnings management practices through two approaches, namely, real earnings management and accrual earnings management, financial and non-financial conditions can also influence the actions of managers in carrying out earnings management. However, several previous studies have had different results with various explanations. It is known that this difference is caused by different periods, company objects and different research backgrounds.

For further researchers, it is hoped that they can try to conduct a literature study with research with the latest period, research objects of various companies from various available sectors in order to increase knowledge and be able to see more broadly about conditions and factors such as what triggers earnings management actions.

\section{References}

Asghar, A., Sajjad, S., Shahzad, A., \& Matemilola, B. T. (2020). Role of Discretionary Earning Management in Corporate Governance-Value and Corporate GovernanceRisk Relationships. 20(4), 561-581. Https://Doi.Org/10.1108/Cg-11-2019-0347

Astuti, C. D., \& Pangestu, N. (2019). Kualitas Audit, Karakteristik Perusahaan Dan. Jurnal Media Riset Akuntansi, Auditing \& Informasi, 19(2), 191-208.

Baskaran, S., Nedunselian, N., Ng, C. H., Mahadi, N., Zaleha, S., \& Rasid, A. (2020). Earnings Management: A Strategic Adaptation or Deliberate Manipulation? 27(2), 369-386. Https://Doi.Org/10.1108/Jfc-07-2019-0098

Bei, T. D. I. (2017). Analisis Faktor Yang Mempengaruhi Manajemen Laba Pada Perusahaan Manufaktur Yang Tercatat Di Bei 1. 2017, 27-28.

Buana, U. S., Vania, A. S., Nugraha, E., \& Nugroho, L. (2018). Does Earning Management Happen In Islamic Bank? (Indonesia and Malaysia Comparison) Adela Sarah Vania Erik Nugraha Lucky Nugroho Finance Finance and and Of Commerce of Commerce International International. 4(2), 47-59.

Dechow, P. M., Sloan, R. G., \& Sweeney, A. P. (1996). Causes and Consequences of Earnings Manipulation: An Analysis of Firms Subject To Enforcement Actions by the Sec. Contemporary Accounting Research, 13(1), 1-36. Https://Doi.Org/10.1111/J.1911-3846.1996.Tb00489.X

E Janrosl, V. S., \& Lim, J. (2019). Analisis Pengaruh Good Corporate Governance Terhadap Manajemen Laba Pada Perusahaan Perbankan Yang Terdaftar Di Bei. Owner, 3(2), 226. Https://Doi.Org/10.33395/Owner.V3i2.144

Graham, J. R., Harvey, C. R., \& Rajgopal, S. (2005). The Economic Implications of Corporate Financial Reporting. Journal of Accounting and Economics, 40(1-3), 3- 
73. Https://Doi.Org/10.1016/J.Jacceco.2005.01.002

Gunny, K. A. (2010). The Relation between Earnings Management Using Real Activities Manipulation and Future Performance: Evidence from Meeting Earnings Benchmarks. Contemporary Accounting Research, 27(3), 855-888. Https://Doi.Org/10.1111/J.1911-3846.2010.01029.X

Herawaty, V. 2008. "Peran Praktik Corporate Governance Sebagai Moderating Variable Dari Pengaruh Earnings Management Terhadap Nilai Perusahaan." Simposium Nasional Akuntansi XI. Pontianak.

Jelanti, D. (2020). Pengaruh Rasio Profitabilitas, Free Cash Flow, Dan Leverage Terhadap Manajemen Laba. 3(2), 289-303.

Lin, J. W., \& Hwang, M. I. (2010). Audit Quality, Corporate Governance, and Earnings Management: A Meta-Analysis. International Journal of Auditing, 14(1), 57-77. Https://Doi.Org/10.1111/J.1099-1123.2009.00403.X

Mahrani, M., \& Soewarno, N. (2018). The Effect of Good Corporate Governance Mechanism and Corporate Social Responsibility on Financial Performance with Earnings Management as Mediating Variable. 3(1), 41-60. Https://Doi.Org/10.1108/Ajar-06-2018-0008

Ningsih, S. (2017). Earning Management Melalui Aktivitas Riil Dan Akrual. Jurnal Akuntansi Dan Pajak, 16(01), 55-66. Https://Doi.Org/10.29040/Jap.V16i01.22

Niranda, H. G., \& Muid, D. (2020). Analisis Faktor - Faktor Yang Mempengaruhi Manajemen Laba (Studi Empiris Perusahaan Manufaktur Yang Terdaftar Di Bursa Efek Indonesia Tahun 2016-2017). Diponegoro Journal of Accounting, 9(2), 1-14.

Pengaruh, A., Perusahaan, U., Institusional, K., \& Kepemilikan, D. A. N. (2019). Analisis Pengaruh Ukuran Perusahaan, Laverage, Kepemilikan Institusional, Dan Kepemilikan Manajerial Terhadap Manajemen Laba. 8, 148-158.

Redaksi, P., Cahyaningtyas, F., Hermawan, A., Fakhriyyah, D. D., Diyanti, F., Sari, D. M., Faisol, M., Temalagi, S., Ayu, I. G., Omika, A., \& Bahri, S. (N.D.). No Title.

Roychowdhury, S. (2006). Earnings Management through Real Activities Manipulation. Journal of Accounting and Economics, 42(3), 335-370. Https://Doi.Org/10.1016/J.Jacceco.2006.01.002

Sari, N. H., \& Ahmar, N. (2014). Revenue Discretionary Model Pengukuran Manajemen Laba: Berdasarkan Sektor Industri Manufaktur Di Bursa Efek Indonesia. Jurnal Akuntansi Dan Keuangan, 16(1), 43-51. Https://Doi.Org/10.9744/Jak.16.1.43-51

Scott, W. R. (2012). Financial Accounting Theory, 6 Th Edition Prentice Hall

Shah, M. et al. (2020). The Development Impact of PT. Medco E \& P Malaka on Economic Aspects in East Aceh Regency. Budapest International Research and Critics Institute-Journal (BIRCI-Journal). P. 276-286.

Suprianto, E., \& Setiawan, D. (2020). Jurnal Akuntansi Dan Auditing Indonesia Accrual Earning Management and Future Performance: Evidence from Family Firm in Indonesia. 24(June).

Yannizar, et al. (2020). Analysis of Good Corporate Governance, Free Cash Flow, Leverage towards Earning Management, and Shareholder Wealth in Service Sector Companies Listed on the Indonesia Stock Exchange. Budapest International Research and Critics Institute-Journal (BIRCI-Journal).P. 2567j-2567v.

Wibowo, L. W., \& Herawaty, V. (2019). Analisis Kinerja Keuangan Yang Mempengaruhi Manajemen Laba Dengan Kepemilikan Asing Sebagai Variabel Moderasi. Prosiding Seminar Nasional Cendekiawan, 2. Https://Doi.Org/10.25105/Semnas.V0i0.5805 